\title{
Labor Unrest in the Ready-Made Garment Industry of Bangladesh
}

\author{
Shaheen Ahmed ${ }^{1}$, Mohammad Zahir Raihan ${ }^{2} \&$ Nazrul Islam² \\ ${ }^{1}$ Assistant Professor, Bangladesh Open University, Bangladesh \\ ${ }^{2}$ Associate Professor, Bangladesh Open University, Bangladesh, Bangladesh Open University, Bangladesh \\ ${ }^{2}$ Professor and Dean, Eastern University, Dhanmondi, Dhaka, Bangladesh \\ Correspondence: Shaheen Ahmed, Assistant Professor, Bangladesh Open University, Gazipur-1705, Bangladesh. \\ E-mail: shaheenmahmed@yahoo.com
}

Received: March 14, 2013

Accepted: March 30, 2013

Online Published: July 12, 2013

doi:10.5539/ijbm.v8n15p68

URL: http://dx.doi.org/10.5539/ijbm.v8n15p68

\begin{abstract}
For the last two decades, Ready-Made Garment (RMG) Industry has been the life-blood of the economy of Bangladesh. This sector accounted for about $80 \%$ of the total export earnings of the country. In the recent years, it has been observed that the workers have came down in the street and making insurgence on their demand and tried to destruct public properties. As a result, companies are losing working-hours and production targets. It also hampers export earnings and the image of the country to the international markets. In this connection, this study tried to find out the factors behind the unrest in the ready-made garment industry of Bangladesh and identifies some measures to improve the situation. In this study, 244 workers were interviewed from the different garment factories located in Savar and Gazipur district of Bangladesh. Data were analyzed with factor analysis, regression model, and by using other suitable statistical tools. The results show that the main causes of labor unrest include lack of minimum facility and safety at work, sub-standard living conditions, deferred payment of wages and benefits, international conspiracy and coercive role of the law enforcing agency, too much dependency on buyers, pressures from the workers and local terrorists, use of workers by others and rumors, un-fulfillment of education demands of their children, distorted minded workers, political instability of the country, too much workload, lack of promotion opportunity, insufficient wages to survive etc. If the policy makers of Bangladesh consider these causes and make policies to overcome the problems the labor unrest in garment sector may be minimized.
\end{abstract}

Keywords: labor unrest, ready-made garment, minimum wages, deferred payment, facility and safety

\section{Background}

Ready-made garment industry has a paramount importance in the economy of Bangladesh. About $80 \%$ of the total export of Bangladesh comes from this sector. It has also been observed from the statistics that since 1996 to 2011 the total export of ready-made garment sector has been expanded substantially. In 2010-2011 financial year $78.15 \%$ of the total export was from ready-made garment industry (Table 1). However, this industry is heavily dependent on the international markets. After the withdrawal of quota protection in 2005, it was perceived that this industry will have severe negative impact under the new WTO arrangement. But Bangladeshi ready-made garment industry faced it intellectually and the earning of this sector has been increased steadily. This has been attributed by the experts as the low labor cost and the efficiency of the Bangladeshi workers. 
Table 1. Statement on export of RMG and total export of Bangladesh

\begin{tabular}{cccc}
\hline Year & Export of RMG (In million US dollar) & Total Export of Bangladesh (In million US dollar) & \% of RMG's to Total Export \\
\hline $1996-1997$ & 3001.25 & 4418.28 & 67.93 \\
$1997-1998$ & 3781.94 & 5161.20 & 73.28 \\
$1998-1999$ & 4019.58 & 5312.86 & 75.67 \\
$1999-2000$ & 4349.41 & 5752.20 & 75.61 \\
$2000-2001$ & 4859.83 & 6467.30 & 75.14 \\
$2001-2002$ & 4583.75 & 5986.09 & 76.57 \\
$2002-2003$ & 4912.09 & 6548.44 & 75.01 \\
$2003-2004$ & 5686.09 & 7602.99 & 74.79 \\
$2004-2005$ & 6417.67 & 8654.52 & 74.15 \\
$2005-2006$ & 7900.80 & 10526.16 & 75.06 \\
$2006-2007$ & 9211.23 & 12177.86 & 75.64 \\
$2007-2008$ & 10699.80 & 14110.80 & 75.83 \\
$2008-2009$ & 12347.77 & 15565.19 & 79.33 \\
$2009-2010$ & 12496.72 & 16204.65 & 77.12 \\
\hline
\end{tabular}

Source: Export Promotion Bureau Compiled by BGMEA.

One of the remarkable features of the Bangladeshi industry is the entry of women workers into the industrial employment system. At present, 3.60 million workers are working in the ready-made garment industry of Bangladesh where $85 \%$ of them are female who are mainly from rural areas of the country (Table 2). As such, ready-made garment industry opened a new door for the rural unemployed and illiterate women to engage themselves in the financial activities of the economy of Bangladesh. Labor Force survey (Bangladesh Bureau of Statistics 1991, 1992) shows that although male employment in the manufacturing sector is more or less stagnant, female employment is increasing significantly which is attributed by the social development in Bangladesh.

Table 2. Growth of the industry and employment in RMG industry of Bangladesh

\begin{tabular}{ccc}
\hline Year & Number of Garment Factories & Employment (in Million Workers) \\
\hline $1996-1997$ & 2503 & 1.300 \\
$1997-1998$ & 2726 & 1.500 \\
$1998-1999$ & 2963 & 1.500 \\
$1999-2000$ & 3200 & 1.600 \\
$2000-2001$ & 3480 & 1.800 \\
$2001-2002$ & 3618 & 1.800 \\
$2002-2003$ & 3760 & 2.000 \\
$2003-2004$ & 3957 & 2.000 \\
$2004-2005$ & 4107 & 2.000 \\
$2005-2006$ & 4220 & 2.200 \\
$2006-2007$ & 4490 & 2.400 \\
$2007-2008$ & 4743 & 2.800 \\
$2008-2009$ & 4925 & 3.500 \\
$2009-2010$ & 5063 & 3.600 \\
$2010-2011$ & 5150 & 3.600 \\
\hline
\end{tabular}

Source: http://www.bgmea.com.bd/home/pages/aboutus dated 1 December 2012.

The current competitive strength of RMG producing firms in Bangladesh is essentially emanated from availability of extremely cheap labor force and their efficiency (Bhattacharya, 1996). In terms of labor cost, Bangladesh is well positioned and compares favorably with other Asian countries in this regard. The per hour cost of labor in Bangladesh is \$0.25, compared to \$0.34 in Indonesia, \$0.34 in Pakistan, \$0.46 in Sri Lanka, $\$ 0.48$ in China and $\$ 0.57$ in India (Khan, 2008). This indicates that the buyers of ready-made garments are more willing to get the products from Bangladesh due to low labor cost. It is also observed that Bangladesh workers 
are efficient and the ready-made garments products are highly demanded by the international markets.

But the ready-made garment industry is under the threat of continuous unrest in Bangladesh. Workers are not happy with their wages and the working environments of the factories. The issue of labor unrest is not only related to worker's wages but also related to other non-wage issues such as, high overtime work, lack of leisure and holidays, overall working environment, etc. Paul-Majumder (2007) found that demand for weekly holiday is a major reason for worker's unrest during 2006. It is observed that the workers are engaged in work for all most all days. As far as buyers are concerned, they blame mistrust, rude behaviors of the managers are the reasons for RMG unrest in Bangladesh (The New Age, Wednesday, August 04, 2010). In addition, the wages given to the garment workers are not adequate to survive. Absar (2001) argues that low wages and sub-standard living condition are major causes of labor unrest in the RMG industry of Bangladesh. In the garment industry, the rights of the labors are not well protected. The trade unions are not allowed. The child labors are allowed to work over there (Islam and Ahmed 2010).

The most common reasons of labor unrest in the garment sector of Bangladesh are unpaid wage and the deferred payment. Some garment owners do not give salaries and overtime allowance to the workers on time (Uddin and Jahed 2007). Although the owners claim that more than $90 \%$ garment factories pay worker's wages within 1st and 2nd week of the month (Rahman, Bhattacharya and Moazzem 2008). National political environment has significant influence on the ready-made garment unrest in Bangladesh that has been found in the study of Uddin and Jahed (2007). According to New Age Metro (2008), the RMG sector of Bangladesh has experienced at least 72 incidents of labor unrest over demand for payment of dues. It has been reveals a report of the Bangladesh Institute of Labor Studies that in the past six months, from January 1 to June 30 labor unrest has been occurring in Bangladesh. According to the report, 41 of the incidents took place in connection with the demand for payment of their dues. In 13 cases, the workers used streets to protest for the killing or torture of their colleagues. Among others, declaration of lay-off or closure, and termination and curtailment of leave or holiday were the causes of demonstrations and unrest in this sector. Daily Star (May, 2012) reported that the garment workers engage in violent clashes at times on rumors or slightest instigations for lack of proper counseling and poor relations with the management. Except for the massive labor unrest for wage hike in 2010, most other incidents of unrest in the sector happened either following rumors of death of fellow workers or on instigation.

New Age (2012a) also reported that RMG sector is experiencing tough times. The sector has been reverberated with labor rampage, killings, wage disputes and disappearance incidents. The sector experienced serious unrests during mid-July 2010. Then, several thousands of apparel workers went on rampage in different industrial areas demanding a wage structure providing a minimum monthly pay of Tk 5,000. It also reported that the frequent unrest in the sector pertaining to their working conditions, wage and other rights issues have hampered the production and the economy (New Age, May, 2012b). The News Today (2012) reported that the causes for the most of the recent labor disputes were not solely due to demand for salary increments. The nature of the unrest clearly indicated that a well-coordinated and orchestrated conspiracy led to the unrest created by outsiders. Bjorn Claeson (2010) found that the failure of garment factories to implement the minimum wage set for garment workers and a lack of recognized labor unions were the key reasons for the recent unrest.

Worker unrest took place on June 21, 2010 for implementing minimum wages of US \$70 per month. In that clash, two hundred peoples were injured and thirty factories were ransacked (Islam and Ahmad 2010). One of the reasons for this unrest in the garment industry is legal and institutional failures to ensure labor rights (Islam and Ahmed, 2010). Most of the garment factories in Bangladesh hardly follow the labor laws and ILO conventions (Islam and Ahmed, 2010). The industry leaders believe that the current bout of the unrest did not stem from the demand for wage hike and said the unrest and vandalism in the factories were not the acts of regular workers (Naim-Ul-Karim 2012). Recent Ashulia's unrest has reportedly spread to many other apparel hubs as the workers took to the streets to express solidarity with their colleagues and also demand wage hike.

Abrar Ahmed Apu (2007) identified that low wages, higher wages discrimination/gap in organizational hierarchy, lack of compliance (no weekly day off, no festival bonus, compulsory over-time, but fraction payment or no payment), no responsible organizations who will listen labors' needs and demands; death of any garment labors in the factory premises, could be by fire-smoke, electrified and labor pain for pregnant women; distorted minded boys/males labors create havoc of unrest to press their illegal demands; local influential (could be mastans-mastans are those who are involved in local terrorist or miscreant activities) trading of garment wastes or jhoot (the trade of garments wastes is called jhoot business in local language of Bangladesh), sometimes creates unwanted unrest in the clothing manufacturing areas; and some believe international politics willing creates labor unrest, thus intentionally spread the news of labor unrest in the industry to take unprivileged advantages. In another study, Rahat Ferdous (2012) found that the reason behind the labor unrest is 
the absence of legal and institutional arrangements to ensure labor rights in the RMG sector. Many of the garments factories in Bangladesh are alleged not to comply with the Labor Law and ILO conventions. The main reason for labor unrest is inadequate wages of the workers. Mohammad Sirajul Islam and Sonia Ahmad (2010) identified that conveyance, lunch bill and enhancement of casual leave, increase of monthly minimum wages from Tk 1662 to Tk 5000; low house rent and better supply of water and gas are the reasons for the labor unrest in the ready-made garment industry of Bangladesh.

In another study, Refayet Ullah Mirdha (2012) found that the rumor, fear of job loss, Jhoot business, case with police stations, fear of shutdown of factories, arrears, checking at entry point and identity cards, pay hike and discrimination in grades, bad relation with workers and mid level management, provocation by locally influential people and international conspirators and some NGOs, fear of police and role of industrial police, sudden order cut by international buyers, production in piece rate, accommodation and higher house rent, lack of motivational training program, inflation etc. are also the reasons for labor unrest in ready-made industry of Bangladesh.

Keeping the importance of the ready-made garment industry in the economy of Bangladesh in mind, this study mainly identified the reasons for the continuous labor unrest in this sector of Bangladesh.

\section{Objectives of the Study}

The main objective of this study is to identify the factors related to labor unrest in ready-made garment industry of Bangladesh. The specific objectives are as follows.

- $\quad$ To describe the ready-made garment industry of Bangladesh;

- To identify the significant factors related to the unrest in ready-made garment industry of Bangladesh.

\section{Methodology of the Study}

This study used both primary and secondary data. Primary data were collected from the interview of 244 workers from ten leading garment companies located in Savar and Gazipur district. For the last couple of years it has been observed that the majority of the labor unrest has been took place in these districts and for this reason Savar and Gazipur district were selected purposively to collect data to conduct this study. A structured questionnaire with 83 items was used to collect data. The secondary data were collected from the journals, periodicals, annual reports of Bangladesh Garment Manufacturers and Exporters Association (BGMEA) etc.

In collection of data, a group of MBA students of Eastern University, Bangladesh was used. They were given adequate training with the questions of the questionnaire and supervised closely so that they can conduct interview with the garment workers properly to collect data regarding this study. The samples were selected by using convenience sampling method. After collection of data, incomplete, and biased, or abnormally answered data were discarded through a thorough scrutinizing process. The reliability of 83 items in the questionnaire has been tested by using SPSS software and the Alpha Coefficient was 0.9453 in the acceptable limit as per Nunnally (1967 and 1978).

Both descriptive and inferential analysis was done with the survey data. Descriptive statistics like mean, standard deviation, simple percentages were used describe the present situation of the ready-made garment companies of Bangladesh. Inferential statistics like Factor Analysis (FA) was used to separate the factors related to the unrest of the ready-made garment workers of Bangladesh. Multiple Regression Analysis (MRA) was used to identify the significant factors from the factors identified through factor analysis. The overall reasons for the unrest in ready-made garment industry were defined by the personal and socioeconomic status of the workers.

\section{Analysis and Interpretations}

The analysis part of the study contains two important segments such as (i) the results of factor analysis and (ii) the relations between the overall dissatisfaction and the labor unrest factors of the ready-made garment workers of Bangladesh.

\subsection{Results of Factor Analysis-Labor Unrest Factors}

The reasons for the labor unrest in ready-made garment industry of Bangladesh were identified through factor analysis. The analysis identified 18 factors responsible for the unrest (Table 3). These factors together explain $91.259 \%$ of the variance of the data set. The most important unrest factor is 'Long Working Hour and Layoff' with eigenvalue of 27.62 and variance of $33.68 \%$. The second important unrest factor is 'Lack of Minimum Facility and Safety' with eigenvalue of 5.93 followed by Sub-Standards Living Conditions (5.425), Deferred Benefits (4.599), International Conspiracy and Coercive Role of the Law Enforcing Agency (4.356), Too much Dependence on Buyers (3.73), Pressures from the Workers and Mastans (3.29), Use of Workers by Others and 
Rumors (2.90), Price Hike of Necessary Items (2.52), Un-fulfillment of Education Demands of the Children (2.31), Distorted Minded Workers (2.19), Political Instability of the Country (1.90), Too Much and Inhuman Workload (1.81), Reluctance of the Government Regulatory Bodies (1.58), No Promotion Opportunity (1.32), Wages are not Paid On Time (1.27), Poor Working Environment (1.18), and Insufficient Wages for Fulfilling Basic Needs (1.01). This indicates that there are number of important factors associated to the labor unrest in garment sector of Bangladesh.

Table 3. Total variance explained

\begin{tabular}{lccc}
\hline \multicolumn{1}{c}{ Components } & \multicolumn{3}{c}{ Initial Eigenvalues } \\
\cline { 2 - 4 } 1. Long Working Hour and Layoff & Total & \% of Variance & Cumulative \% \\
2. Lack of Minimum Facility and Safety & 27.617 & 33.679 & 33.679 \\
3. Sub-Standards Living Conditions & 5.928 & 7.229 & 40.908 \\
4. Deferred Benefits & 5.425 & 6.616 & 47.524 \\
5. International Conspiracy and Coercive Role of the Law Enforcing & 4.599 & 5.609 & 53.133 \\
Agency & 4.356 & 5.313 & 58.446 \\
6. Too much Dependence on Buyers & & & 62.994 \\
7. Pressures from the Workers and Mastans & 3.730 & 4.548 & 67.004 \\
8. Use of Workers by Others and Rumors & 3.289 & 4.010 & 70.540 \\
9. Price Hike of Necessary Items & 2.899 & 3.535 & 73.613 \\
10. Un-fulfillment of Education Demands of the Children & 2.520 & 3.073 & 76.425 \\
11. Distorted Minded Workers & 2.306 & 2.812 & 78.995 \\
12. Political Instability of the Country & 2.108 & 2.570 & 81.309 \\
13. Too Much and Inhuman Workload & 1.897 & 2.314 & 83.518 \\
14. Reluctance of the Government Regulatory Bodies & 1.811 & 2.208 & 85.438 \\
15. No Promotion Opportunity & 1.575 & 1.920 & 87.049 \\
16. Wages are not Paid on Time & 1.321 & 1.611 & 88.598 \\
17. Poor Working Environment & 1.271 & 1.550 & 90.033 \\
18. Insufficient Wages for Fulfilling Basic Needs & 1.176 & 1.434 & 91.259 \\
\hline
\end{tabular}

Extraction Method: Principal Component Analysis.

Table 4 shows that the main factor for the labor unrest in Bangladesh is long working hour and the sudden layoffs. The workers used to work at the factory from dawn to dusk with overtime which is very low in amount. This factor has been formed with 20 items or variables relating to labor unrest. All the variables have high factor loadings indicating that the variables have strong relationship with the factor. This can be attributed by undue overstay of the workers that is compelled by the factory owners in this industry. 
Table 4. Long working hour and layoff

\begin{tabular}{|c|c|c|}
\hline & Variables & Factor Loading \\
\hline 1 & Long working hours & .902 \\
\hline 2 & Declaration of lay-off or closure of factory without any reasons & .764 \\
\hline 3 & Workers have no bargaining power with the employer & .722 \\
\hline 4 & Workers are not getting lunch bill as it would be & .710 \\
\hline 5 & Workers over-time work is compulsory & .705 \\
\hline 6 & Workers cannot spend for medical & .679 \\
\hline 7 & Lack of recognized labor unions & 679 \\
\hline 8 & Workers have low social status & 678 \\
\hline 9 & Workers' unable to save money for their future & .638 \\
\hline 10 & Workers are deprived of from festival bonus & .611 \\
\hline 11 & Workers want to enhance their casual leave & .601 \\
\hline 12 & Workers have limited access to social amenities & .588 \\
\hline 13 & Workers have no recognition in their family, friends and society & .576 \\
\hline 14 & Irregular payment of overtime work & .566 \\
\hline 15 & Workers are unable to maintain their family & .555 \\
\hline 16 & Ruling party create problem to keep the eyes of people away from their failure & .535 \\
\hline 17 & No rule is implemented for the regular workers & .535 \\
\hline 18 & Poor relation with workers and management & .523 \\
\hline 19 & Mistrust between workers and owners & .500 \\
\hline 20 & Workers have no assurance of payment & .446 \\
\hline
\end{tabular}

The second important labor unrest factor is lack of minimum facility and safety. In Garment Companies of Bangladesh, minimum facilities for canteen, prayer room, washing room, toilets, child care etc. are hardly adequate. Moreover, the safety measures are not up to the mark so that accidents are occurring frequently (Table 5). Frequent accidents also indicate that the safety measures followed are hardly up to the standards in this industry. This factor has been formed with 10 variables with very high factor loadings.

Table 5. Lack of minimum facility and safety

\begin{tabular}{llc}
\hline & & \multicolumn{1}{c}{ Variables } \\
\hline 1 & Workers are deprive of getting minimum facilities in the factory & .882 \\
2 & lack of occupational safety measures & .867 \\
3 & Workers family problems & .836 \\
4 & Lack of adjustment with spouse and other family members & .742 \\
5 & No responsible organizations who will listen to labors' problems & .667 \\
6 & Workers are frustrated with their future & .664 \\
7 & Accommodation problem of workers and high house rent & .627 \\
8 & Termination of worker in lame excuse or no reason & .606 \\
9 & Workers feel hassle checking at entry point and identity cards & .581 \\
10 & Management usually undermine workers & .551 \\
\hline
\end{tabular}

The third important factor for the labor unrest is sub-standard living conditions of the workers (Table 6). All most all companies do not have housing facilities. Therefore, workers live nearby the factory in the rental houses where the conditions are very poor. They are also unable to higher good house with the financial benefits they receive. Ten variables constituted this factor with high factor loadings values. 
Table 6. Sub-standards living conditions

\begin{tabular}{llc}
\hline & \multicolumn{1}{c}{ Variables } & Factor Loading \\
\hline 1 & Sub-standard living (residence) condition & .837 \\
2 & Workers are not given value of their voice & .786 \\
3 & Workers are not getting conveyance when coming twice a day & .653 \\
4 & Downgrading/declination of the society values & .635 \\
5 & Workers have no recognition of their work & .614 \\
6 & Workers are not getting dinner while working at night shift & .603 \\
7 & Physical abuse by the supervisor & .558 \\
8 & Workers are absent from social program & .528 \\
9 & Workers want to increase their wages & .497 \\
10 & Killing or torture on their colleagues & .439 \\
\hline
\end{tabular}

Table 7 shows that deferred payment of benefits is another reason for the unrest in ready-made garment industry of Bangladesh. The benefits like bonus, overtime etc are not given on time. These are paid after a long time of the work. This creates frustration among the workers.

Table 7. Deferred benefits

\begin{tabular}{|c|c|c|}
\hline & Variables & Factor Loading \\
\hline 1 & Deferred festival bonus & .859 \\
\hline 2 & Workers' wages are very low & .713 \\
\hline 3 & Workers have no mental peace & .702 \\
\hline 4 & Legal and institutional failures to ensure labor rights & .691 \\
\hline 5 & Workers are not getting weekly holiday & .576 \\
\hline
\end{tabular}

Table 8 to Table 21 show the labor unrest factors named International Conspiracy and Coercive Role of the Law Enforcing Agency, Too much Dependence on Buyers, Pressures from the Workers and Mastans, Use of Workers by Others and Rumors, Price Hike of Necessary Items, Un-fulfillment of Education Demands of the Children, Distorted Minded Workers, Political Instability of the Country, Too Much and Inhuman Workload, Reluctance of the Government Regulatory Bodies, No Promotion Opportunity, Wages are not Paid On Time, Poor Working Environment, and Insufficient Wages for Fulfilling Basic Needs.

Table 8. International conspiracy and coercive role of the law enforcing agency

\begin{tabular}{llc}
\hline & \multicolumn{1}{c}{ Variables } & Factor Loading \\
\hline 1 & Some international conspirators and some NGOs work for creates unrest & .706 \\
2 & Coercive role of law-enforcing agencies & .679 \\
3 & International politics by the competitor country creates labor unrest & .565 \\
4 & Opposition party influence workers to make unrest to show the failure of government & .523 \\
5 & Personal clash of garment owner with the local leader & .488 \\
\hline
\end{tabular}

Table 9. Too much dependence on buyers

\begin{tabular}{|c|c|c|}
\hline & Variables & Factor Loading \\
\hline 1 & Sudden order cut by international buyers & .925 \\
\hline 2 & Implementation of new technology & .732 \\
\hline 3 & Trading of garment wastes & .696 \\
\hline 4 & Workers living standard is declining & .503 \\
\hline
\end{tabular}


Table 10. Pressures from the workers and Mastans

\begin{tabular}{llc}
\hline & \multicolumn{1}{c}{ Variables } & Factor Loading \\
\hline 1 & Workers want to implement minimum wages rate & .793 \\
2 & Local influential persons who want to have donation & .720 \\
3 & Planned conspiracy led to the unrest created by outsiders & .557 \\
4 & Demand for payment of dues & .557 \\
\hline
\end{tabular}

Table 11. Use of workers by others and rumors

\begin{tabular}{llc}
\hline & \multicolumn{1}{c}{ Variables } & Factor Loading \\
\hline 1 & Workers may be used by the competitor garment factory & .820 \\
2 & Rumors of detention or death of fellow workers or on instigation & .770 \\
3 & Workers are in fear of shutdown of factories & .549 \\
4 & Workers has no job security & .416 \\
\hline
\end{tabular}

Table 12. Price hike of necessary items

\begin{tabular}{llc}
\hline & \multicolumn{1}{c}{ Variables } & Factor Loading \\
\hline 1 & The inflation in the daily necessary items like food and other items & .822 \\
2 & Workers dispute are not solved for long time & .574 \\
\hline
\end{tabular}

Table 13. Un-fulfillment of education demands of the children

\begin{tabular}{llc}
\hline & \multicolumn{1}{c}{ Variables } & Factor Loading \\
\hline 1 & Workers cannot meet the education requirement of their children & .812 \\
2 & Wages discrimination among the workers & .535 \\
3 & Workers cannot spend money for recreation & .505 \\
4 & Workers have no leisure during their daylong work & .430 \\
\hline
\end{tabular}

Table 14. Distorted minded workers

\begin{tabular}{|c|c|c|}
\hline & Variables & Factor Loading \\
\hline 1 & Distorted minded workers want to make unrest & .803 \\
\hline 2 & Worker community have no concern for the society & .556 \\
\hline 3 & Workers has innate anger to the rich people & .534 \\
\hline 4 & Deduction of workers wages for lame excuse & .481 \\
\hline
\end{tabular}

Table 15 Political instability of the country

\begin{tabular}{|c|c|c|}
\hline & Variables & Factor Loading \\
\hline 1 & Political instability at the national level influences violence & .776 \\
\hline 2 & Supervisor used to use slang language to the workers & .688 \\
\hline 3 & Rude behavior of the supervisor & .535 \\
\hline
\end{tabular}

Table 16. Too much and inhuman workload

\begin{tabular}{|c|c|c|}
\hline & Variables & Factor Loading \\
\hline 1 & Workers to perform inhuman labor for the company & .774 \\
\hline
\end{tabular}

Table 17. Reluctance of the government regulatory bodies

\begin{tabular}{llc} 
& Variables & Factor Loading \\
\hline 1 & Government is reluctant about the rights of workers & .845 \\
\hline
\end{tabular}


Table 18. No promotion opportunity

\begin{tabular}{ccc}
\hline & Variables & Factor Loading \\
\hline 1 & No promotion opportunity are available for the workers & .860 \\
\hline
\end{tabular}

Table 19. Wages are not paid on time

\begin{tabular}{ccc}
\hline & Variables & Factor Loading \\
\hline 1 & Workers are not paid of their wages on time & .686 \\
\hline
\end{tabular}

Table 20. Poor working environment

\begin{tabular}{|c|c|c|}
\hline & Variables & Factor Loading \\
\hline 1 & Workers working environment is poor & .565 \\
\hline 2 & Lack of motivational training program & .525 \\
\hline
\end{tabular}

Table 21. Insufficient wages for fulfilling basic needs

\begin{tabular}{rrc}
\hline & Variables & Factor Loading \\
\hline 1 & Workers are unable to fulfill their basic human needs & .515 \\
\hline
\end{tabular}

Note: extraction method: principal component analysis; varimax with kaiser normalization; a: rotation converged in 114 iterations.

\subsection{Relationships between the Overall Dissatisfaction and the Labor Unrest Factors}

Multiple regressions analysis results show that the factors or reasons related to labor unrest in the ready-made garment industry of Bangladesh are very important to explain the overall dissatisfaction of the workers (Table 22). This means that the reasons for the garment unrest in Bangladesh are from the overall dissatisfaction of the workers in this sector.

Table 22. Model summary

\begin{tabular}{ccccc}
\hline Model & $\mathrm{R}$ & R Square & Adjusted R Square & Std. Error of the Estimate \\
\hline 1 & .786 & .617 & .586 & .9295 \\
\hline
\end{tabular}

a: Predictors: (Constant), REGR factor score 18 for analysis 1 , REGR factor score 17 for analysis 1 , REGR factor score 16 for analysis 1 , REGR factor score 15 for analysis 1 , REGR factor score 14 for analysis 1 , REGR factor score 13 for analysis 1 , REGR factor score 12 for analysis 1, REGR factor score 11 for analysis 1, REGR factor score 10 for analysis 1 , REGR factor score 9 for analysis 1 , REGR factor score 8 for analysis 1 , REGR factor score 7 for analysis 1 , REGR factor score 6 for analysis 1 , REGR factor score 5 for analysis 1 , REGR factor score 4 for analysis 1 , REGR factor score 3 for analysis 1 , REGR factor score 2 for analysis 1 , REGR factor score 1 for analysis 1 .

Analysis of variance shows that the factors concerning labor unrest in the ready-made garment industry of Bangladesh are as a whole responsible for the unrest in this sector (Table 23).

Table 23. Analysis of variance (ANOVA)

\begin{tabular}{|c|c|c|c|c|c|c|}
\hline Model & & Sum of Squares & $\mathrm{df}$ & Mean Square & $\mathrm{F}$ & Sig. \\
\hline \multirow[t]{3}{*}{1} & Regression & 313.271 & 18 & 17.404 & 20.143 & .000 \\
\hline & Residual & 194.401 & 225 & .864 & & \\
\hline & Total & 507.672 & 243 & & & \\
\hline
\end{tabular}

a: Predictors: (Constant), REGR factor score 18 for analysis 1 , REGR factor score 17 for analysis 1, REGR factor score 16 for analysis 1 , REGR factor score 15 for analysis 1, REGR factor score 14 for analysis 1, REGR factor score 13 for analysis 1, REGR factor score 12 for analysis 1, REGR factor score 11 for analysis 1 , REGR factor score 10 for analysis 1, REGR factor score 9 for analysis 1 , REGR factor score 8 for analysis 1, REGR factor score 7 for analysis 1, REGR factor score 6 for analysis 1, REGR factor score 5 for analysis 1, REGR factor score 4 for analysis 1, REGR factor score 3 for analysis 1, REGR factor score 2 for analysis 1, REGR factor score 1 for analysis 1 . b: Dependent Variable: OVERALL. 
Individual factor relationship with the overall dissatisfaction of the ready-made garment workers show that the factors named lack of minimum facility and safety', sub-standards living conditions, deferred benefits, international conspiracy and coercive role of the law enforcing agency, too much dependence on buyers, pressures from the workers and mastans, use of workers by others and rumors, un-fulfillment of education demands of the children, distorted minded workers, political instability of the country, too much and inhuman workload, no promotion opportunity, wages are not paid on time, and insufficient wages for fulfilling basic needs are significantly related to the overall dissatisfaction of the workers. This means that if there is a change in these factors independently there will be a significant impact on the overall dissatisfaction of the workers (Table 24).

\subsubsection{Lack of Minimum Facility and Safety}

This study identified that the most important and significant labor unrest factor is lack of minimum working facility and safety measure. Most of the factories are located in the housing areas of the city which are not built by following the factory rules of the country. This has been often causing accidents and the lives of the workers are going under the threat. Bangladesh Garment Manufacturers and Exporters Association (BGMEA) and the government are not serious to improve the situation in this sector.

\subsubsection{Sub-Standards Living Conditions}

Sub-standard living conditions of the workers are another factor causing unrest in the garment sector of Bangladesh. Due to poor salary, these workers are unable to live in good house. Therefore, the poor living conditions create job dissatisfaction of the workers and that lead to labor unrest in this industry.

\subsubsection{Deferred Benefits}

In garment companies of Bangladesh, the salary is given after the 15th of the month in order to minimize job turn over in the factory. In addition to this, the benefits like bonus, overtime, etc payments are given after an indefinite period of time that creates labor unrest in the industry.

\subsubsection{International Conspiracy and Coercive Role of the Law Enforcing Agency}

Saying goes that the garment industry of Bangladesh is controlled by other competitor exporting countries of the world. If there is a chaos and confusion in this sector, the smooth production will be hampered and the other competing countries will be able to export their products in the international markets. Sometimes, it is observed that the law enforcing agencies sometime create unpleasant situation in the factory for nothing that also makes the workers unhappy.

\subsubsection{Too Much Dependence on Buyers}

The garment export of Bangladesh absolutely depends on the WTO resolution and the agreement of the international buyers. Majority of the companies are fully export oriented. They do not produce products for the local markets. As such, if there is any problem in the GSP of WTO or relationship problem with buyer country, there create a problem in this sector. This causes seasonal layoff at workplace and lead to labor unrest in this industry.

\subsubsection{Pressures from the Workers and Mastans/Terrorists}

Very often, local pressures cause the problem for the factory and workers. Local terrorists often demands donation from the factory owners. When terrorists do not get donation they come with their gang and try to create unrest in the factory premise. In addition to that, the female workers are disturbed by the mustans when they come in the factory and leave the factory after the work.

\subsubsection{Use of Workers by Others and Rumors}

The garment workers are from the rural areas and they are very poor. Therefore, there is a chance to use these workers by the local pressures groups that may go against the interest of the company. Moreover, as these workers are illiterate they become militant when there is a rumor against their interest.

\subsubsection{Un-Fulfillment of Education Demands of the Children}

The workers of the garment factories are unable to send their children to the schools as they are financially incapable to support. This may cause dissatisfaction among the workers in this sector.

\subsubsection{Distorted Minded Workers}

Due to illiteracy of the workers, they are incapable to think positively that creates unrest in the garment industry of Bangladesh. Sometime, it is also observed that workers are frustrated and they have innate anger to the rich 
people. These led them to take part in labor unrest.

\subsubsection{Political Instability of the Country}

Due to political instability of the country, like strike, worker cannot come to the factory to work and they marked absent by the factory managers. This sometime makes workers aggressive and lead to unrest in this sector.

\subsubsection{Too Much and Inhuman Workload}

Too much and inhuman workload is a common phenomenon in this sector of Bangladesh. The payment rate is very poor and the overtime rate is also insignificant for the workers. As a result, they need to work from dawn to dust for a minimum amount of salary. Therefore, workers take part in unrest to establish their rights.

\subsubsection{No Promotion Opportunity}

In garment sector of Bangladesh, promotion is a rare case. Workers had to work in a same position for long period of time. They also reluctant to switch the company because of the risk of losing one month salary that sometime lead to labor unrest.

\subsubsection{Wages Are not Paid on Time}

After 15th of each month the salary is disbursed for the workers in garment workers in Bangladesh. This ill motive of the owners creates labor unrest among the workers.

\subsubsection{Insufficient Wages for Fulfilling of Basic Needs}

The basic needs of the workers are food, clothing and the shelter. However, these are costly in the area where the factories are located. The salary workers receive is extremely inadequate to fulfill these needs. Therefore, they create labor unrest to establish the minimum wages.

Table 24. Coefficients

\begin{tabular}{|c|c|c|c|c|c|}
\hline \multirow[t]{2}{*}{ Factors } & \multicolumn{2}{|l|}{$\begin{array}{l}\text { Unstandardized } \\
\text { Coefficients }\end{array}$} & \multirow[t]{2}{*}{$\begin{array}{l}\text { Standardized } \\
\text { Coefficients }\end{array}$} & \multirow[t]{2}{*}{$\mathrm{t}$} & \multirow[t]{2}{*}{ Sig. } \\
\hline & $\mathrm{B}$ & Std. Error & & & \\
\hline (Constant) & 3.426 & .060 & & 57.578 & .000 \\
\hline 1. Long Working Hour and Layoff & $-7.155 \mathrm{E}-02$ & .060 & -.050 & -1.200 & .231 \\
\hline 2. Lack of Minimum Facility and Safety & .391 & .060 & .271 & 6.565 & .000 \\
\hline 3. Sub-Standards Living Conditions & .114 & .060 & .079 & 1.904 & .058 \\
\hline 4. Deferred Benefits & -.425 & .060 & -.294 & -7.126 & .000 \\
\hline $\begin{array}{l}\text { 5. International Conspiracy and Coercive Role of the } \\
\text { Law Enforcing Agency }\end{array}$ & .335 & .060 & .231 & 5.610 & .000 \\
\hline 6. Too much Dependence on Buyers & .335 & .060 & .232 & 5.622 & .000 \\
\hline 7. Pressures from the Workers and Mastans & .206 & .060 & .142 & 3.449 & .001 \\
\hline 8. Use of Workers by Others and Rumors & .130 & .060 & .090 & 2.186 & .030 \\
\hline 9. Price Hike of Necessary Items & $-2.685 \mathrm{E}-02$ & .060 & -.019 & -.450 & .653 \\
\hline $\begin{array}{l}\text { 10. Un-fulfillment of Education Demands of the } \\
\text { Children }\end{array}$ & .130 & .060 & .090 & 2.182 & .030 \\
\hline 11. Distorted Minded Workers & .425 & .060 & .294 & 7.134 & .000 \\
\hline 12. Political Instability of the Country & .149 & .060 & .103 & 2.501 & .013 \\
\hline 13. Too Much and Inhuman Workload & -.427 & .060 & -.295 & -7.159 & .000 \\
\hline 14. Reluctance of the Government Regulatory Bodies & $7.685 \mathrm{E}-02$ & .060 & .053 & 1.289 & .199 \\
\hline 15. No Promotion Opportunity & -.146 & .060 & -.101 & -2.446 & .015 \\
\hline 16. Wages are not Paid On Time & .266 & .060 & .184 & 4.466 & .000 \\
\hline 17. Poor Working Environment & $-5.565 \mathrm{E}-02$ & .060 & -.039 & -.933 & .352 \\
\hline 18. Insufficient Wages for Fulfilling Basic Needs & .387 & .060 & .268 & 6.486 & .000 \\
\hline
\end{tabular}

a: dependent variable: overall. 


\section{Conclusions and Recommendations}

Labor unrest in ready-made garment industry of Bangladesh has been characterized by eighteen factors responsible identified from this study. These factors are together significantly related to the overall dissatisfaction of the workers in this sector. The main factor for the labor unrest in Bangladesh is long working hour and the sudden layoffs. The workers used to work at the factory from dawn to dusk with overtime which is very low in amount. Although, this factor, independently, is not significantly related to the overall dissatisfaction of the workers, it contributes a lot when all other factors come together with it.

Results show that the labor unrest factors are also independently and significantly related to the overall dissatisfaction of the ready-made garment workers in Bangladesh. This study identified that the factors that are responsible for the labor unrest in ready-made garment industry of Bangladesh are minimum facility and safety, sub-standards living conditions, deferred benefits, international conspiracy and coercive role of the law enforcing agency, too much dependence on buyers, pressures from the workers and mastans, use of workers by others and rumors, un-fulfillment of education demands of the children, distorted minded workers, political instability of the country, too much and inhuman workload, no promotion opportunity, wages are not paid on time, and insufficient wages for fulfilling basic needs are significantly related to the overall dissatisfaction of the workers. This means that if there is a change in these factors, independently, there will be a significant impact on the overall dissatisfaction of the workers. As such these factors might be identified as the main reasons for the labor unrest in ready-made garment industry of Bangladesh. If the policymakers associated to this industry consider the factors identified through this study in making their policy, the situation might be changed and improved. However, there is an ample scope to conduct further investigation to uncover the reasons for the labor unrest in ready-made industry of Bangladesh by taking more samples of workers.

\section{References}

Abrar, A. A. (2007). Labor unrest in Clothing Industry: Reasons and Solutions. Bangladesh Textile Today, First Ever Complete Web Solution for the Textile and Apparel Industry.

Absar \& Syeda, S. (2001). Problem surrounding wages: The Ready-made Garment sector in Bangladesh. Labor and Management Development Journal, 2(7).

Babul, A. (2012). President of Bangladesh Garment and Industrial Workers Federation.

Bhattacharya, D. (1996, November). Climbing Up the Value Chain: RMG Sector in Bangladesh. Seminar on Export Competitiveness in Bangladesh Industry: Achievement and Policy Agenda. Conducted by Bangladesh Institute of Development Studies (BIDS) in collaboration with British Council, Bangladesh.

Bjorn, C. (2010, November). Enemies of the Nation or Human Rights Defenders? Fighting Poverty Wages in Bangladesh. Sweat Free Communities, 30 Blackstone Street Bangor, ME 04401, USA. A Campaign of International Labor Rights Forum.

Jakir, H., Mostafiz, A., \& Afroza, A. (2010). Decent Work and Bangladesh Labor Law: Provisions, Status and Future Directions. BILS.

Khan, S. (2008, January 27). Challenges facing the Garments Industry. The Financial Express, Dhaka, Bangladesh.

Mohammad, A. I. K. (2011). Labor Unrest in the RMG Sector of Bangladesh: A Public-Private Cooperation Perspective. A thesis paper in Master in Public Policy and Governance Program. Department of General and Continuing Education, North-aSouth University.

Mohammad, S. I., \& Sonia, A. (2010). Contemplating Sustainable Solutions to Garments Sector Unrest. The Daily Star.

Mustafizur, R., Debapriya, B., \& Khondaker, G. M. (2007). Dynamics of Ongoing Changes in Bangladesh's Export- Oriented RMG Enterprises: Findings from an Enterprise Level Survey.

Naim-Ul-Karim. (2012). Hundreds of Bangladesh's apparel factories shut down as labor unrest flares.

New Age. (2012a, May). Iqbal Mahmud Traces The Reasons Behind Workers' Unrests During This Month And The Underlying Tensions Triggering These.

New Age. (2012b, May). Aminul's Murderers Killers Still At Large.

New Age Metro. (2008, August 6). RMG labor unrest flares up 72 times in 6 months: 988 injured, 45 arrested, 10,000 sued. 
Nunnally, J. C. (1967). Psychometric Theory. New York: MaGraw-Hill.

Nunnally, J. C. (1978). Psychometric Theory (2nd ed.). New York: MaGraw-Hill.

Paul-Majumder, P. (2007). Bangladeshe Poshak Shilpa Khetre Sama-Adhikarer Abastha Ebong Sramik Ashantosher Sharup. [The State of Equal Right of Workers in the Garments Sector of Bangladesh and Nature and Causes of Labor Unrest] Bangladesh Unnayan Shamiksha, 24(33), 1413.

Rahat Ferdous. (2012). Labor Unrest in the RMG Sector. The Financial Express.

Rahman, M., Bhattacharya, D., \& Moazzem, K. G. (2008). Bangladesh Apparel Sector in Post MFA Era: A Study on the Ongoing Restructuring Process. Centre for Policy Dialogue in association with IFC and SEDF, Dhaka.

Refayet, U. M. (2012). Causes of RMG Unrest. The Daily Star, 6(8).

The Daily Star. (2012, May). Instigations, Rumors Led To Most Incidents.

The New Today. (2012). 20 Hurt as RMG Workers Clash with Cops.

Uddin, M. S., \& Jahed, M. A. (2007). Garments Industry: A Prime Mover of the Social Economic Development of Bangladesh. The Cost and Management, 35(1), 59-70.

\section{Copyrights}

Copyright for this article is retained by the author(s), with first publication rights granted to the journal.

This is an open-access article distributed under the terms and conditions of the Creative Commons Attribution license (http://creativecommons.org/licenses/by/3.0/). 